\title{
THE DEVELOPMENT OF THE URBAN SYSTEM AND THE HIERARCHY OF CITIES IN NEWLY OPENED REGIONS: HOKKAIDO, JAPAN AND SOUTH AFRICA
}

\author{
Ryoji Teraya \\ Faculty of Law and Letters, Ehime University, Matsuyama, Ehime 790-8577, Japan \\ e- mail: teraya@ll.ehime-u.ac.jp
}

\begin{abstract}
This paper aims to analyze the pattern and process of distribution of cities in the newly opened regions by tracing the historical changes of the urban system in Hokkaido, Japan and in the Republic of South Africa. The history of colonization is not so long in the newly opened regions. This means that we can study the genesis and development process of cities from the beginning of colonization. These frontier cities often have the gateway function influencing over the wide surrounding region. The main concern of this study is to find out how urban functions and the urban system change from their beginning in the newly opened region. This study examines the relation between the hierarchy of cities and the locational characteristics of branch offices for the analysis of the postwar urban system in Hokkaido. We can discern the three stages in the development of the urban system in newly opened regions. First stage is the formative period: coastal regions were the centers of the exploitation and port cities were dominant. Second stage is the growth period: the exploitation made great progress in inland regions and the coastal cities and inland cities were in conflict with each other. Third stage is the reorganization period: the economical centers move towards inland regions and the inland capital gets dominant.
\end{abstract}

Key words: newly opened regions, gateway, urban system, Hokkaido, South Africa

\section{INTRODUCTION}

The history of colonization is not so long in the newly opened regions. This means that we can study the genesis and development process of cities from the beginning of colonization. These frontier cities often have a gateway function influencing their wide surrounding regions (Bird 1977). The main concern of this paper is to find out how urban functions and the urban system change from their beginning in the newly opened regions. 
Hokkaido, the second largest island in Japan, is situated in the northern part of Japan and was the only frontier developed and settled after the Meiji Era (1868-1912). Due to these conditions, Hokkaido has some peculiar features in comparison with the rest of Japan, for example, its cool climate, the presence Shicho (sub-prefecture) as the apparatus of government, the low population density, the longer distance among cities and the high degree of the closeness in commodity flow and migration. Hokkaido, therefore, is the most firmly identified regional unit acting as both a uniform and nodal region in Japan.

We can classify African cities into Type A and Type B after Southal (1961). Type A are traditional, old-established cities located in the northern and western Africa. On the other hand, Type B are modern cities that have had with rapid population growth throughout the colonial period. Most Type B are located in the eastern and southern Africa. Cities of South Africa are typically Type B.

This paper aims to analyze the pattern and process of distribution of cities in the newly opened regions by tracing the historical changes of the urban system in Hokkaido, Japan and South Africa.

\section{THE DEVELOPMENT OF THE URBAN SYSTEM IN HOKKAIDO, JAPAN}

\section{The evolution of the urban system}

The population in Hokkaido grew very rapidly from 66,618 persons in 1870 to $5,682,950$ persons in 2000. Changes of rank-size distribution of 576 urban settlements, which means built-up area (Shigaichi) where more than 200 households are clustered together, are shown in Figure 1. Rank size analysis of 576 cities shows that we can discern three stages of the development of the urban system in Hokkaido (Teraya 1985, 1986).

The first stage is the Meiji Era (1868-1912). In this period, most urban settlements were distributed in the southwestern coast (Figure 2). However, urban settlements gradually emerged as regional gateways as frontiers moved from the southwest to the north and east throughout this period,. Hakodate was the primate city. The inclination of the regression line shows considerable changes. This means that Hokkaido did not emerge as the geographical unit in this period.

The second stage is from the Taisho Era(1912-1926) to just after the end of World War II. Throughout this period, Hakodate was the same size as Otaru and Sapporo and there was no primate city. The slope of the regression line got gentler year by year and the urban system had a tendency towards dispersion. In this period, many inland settlements were established and had experienced a higher increase in population than that of coastal settlements.

The third stage is after the 1950's. Throughout this period, the inclination of the regression line got steeper year by year and the urban system had a tendency towards integration. The number of urban settlements was declining in the period, 1964-1976 (Figure 2). Such patterns points to the greater growth of big settlements and the decline of small set- 
tlements. Sapporo became the largest city for the first time in 1948. Since then, the dominance of Sapporo has been strengthened with a population of over 1 million in 1970 and 1.8 million in 2000 .

Therefore, the main urban characters in these three stages are the gateway city, the central place city and the economically advanced city respectively.

Figure 1: Changes of rank - size distribution of Hokkaido settlements, 1879-1976

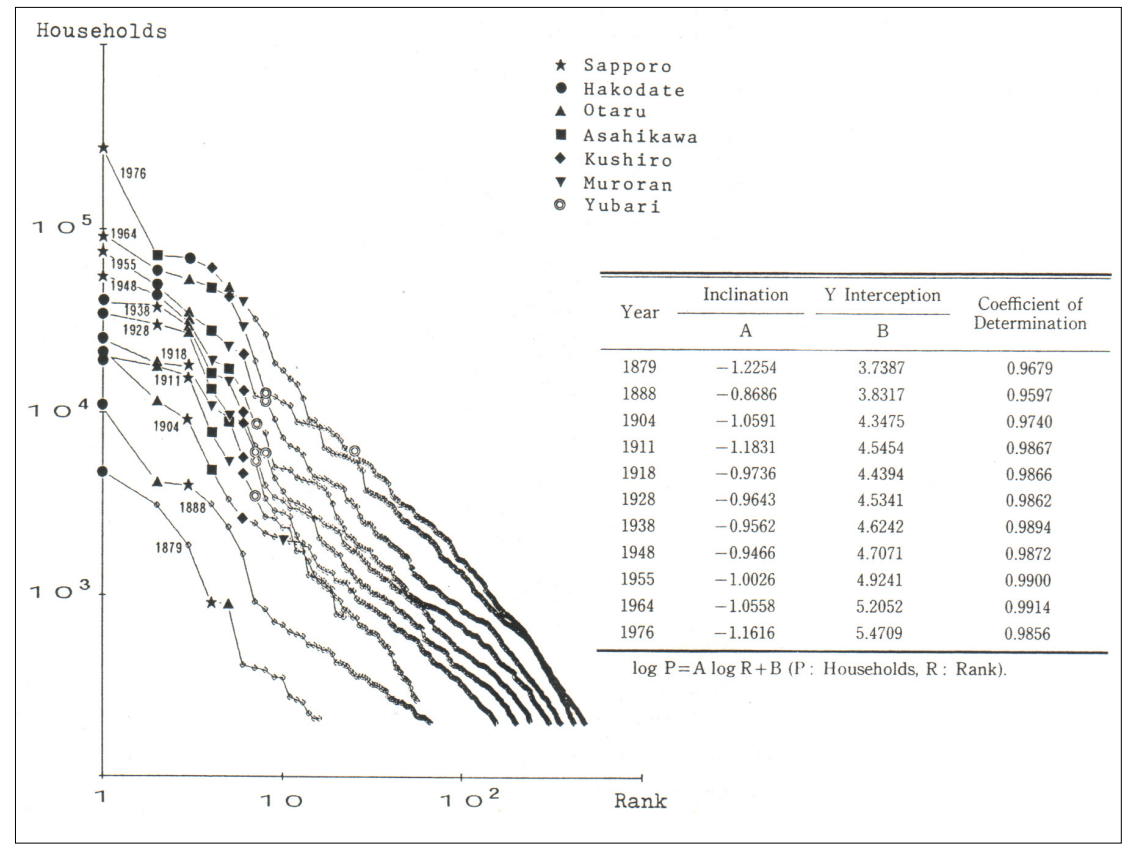

\section{The structure of the urban system in terms of wholesaling trade}

Wholesaling is one of the phenomena that shows interregional economic connections in the spatial development of specialization between production and consumption at the national and regional levels. Hokkaido was divided into two wholesale trading areas by two port cities, Hakodate and Otaru in the Meiji Era (Figure 3). Hakodate had the southern and eastern parts of Hokkaido and Otaru had the northern parts of Hokkaido as its market hinterlands. In the 1920 's, the inland regional capitals (Sapporo,Asahikawa, Obihiro and Kitami) had been developed as wholesaling centers. Therefore, Hokkaido was divided into several hinterlands of these cities.

After World War II, Sapporo has developed as the dominant wholesale center. Figure 4 indicates wholesale trading areas by each stage in the distribution channels. These stages consist of primary wholesalers (buying from producers in more than $50 \%$ of their total purchases and selling to wholesalers in more than $50 \%$ of their total sales), secondary whole- 
Figure 2: Distribution of urban settlements in Hokkaido, 1879-1976.

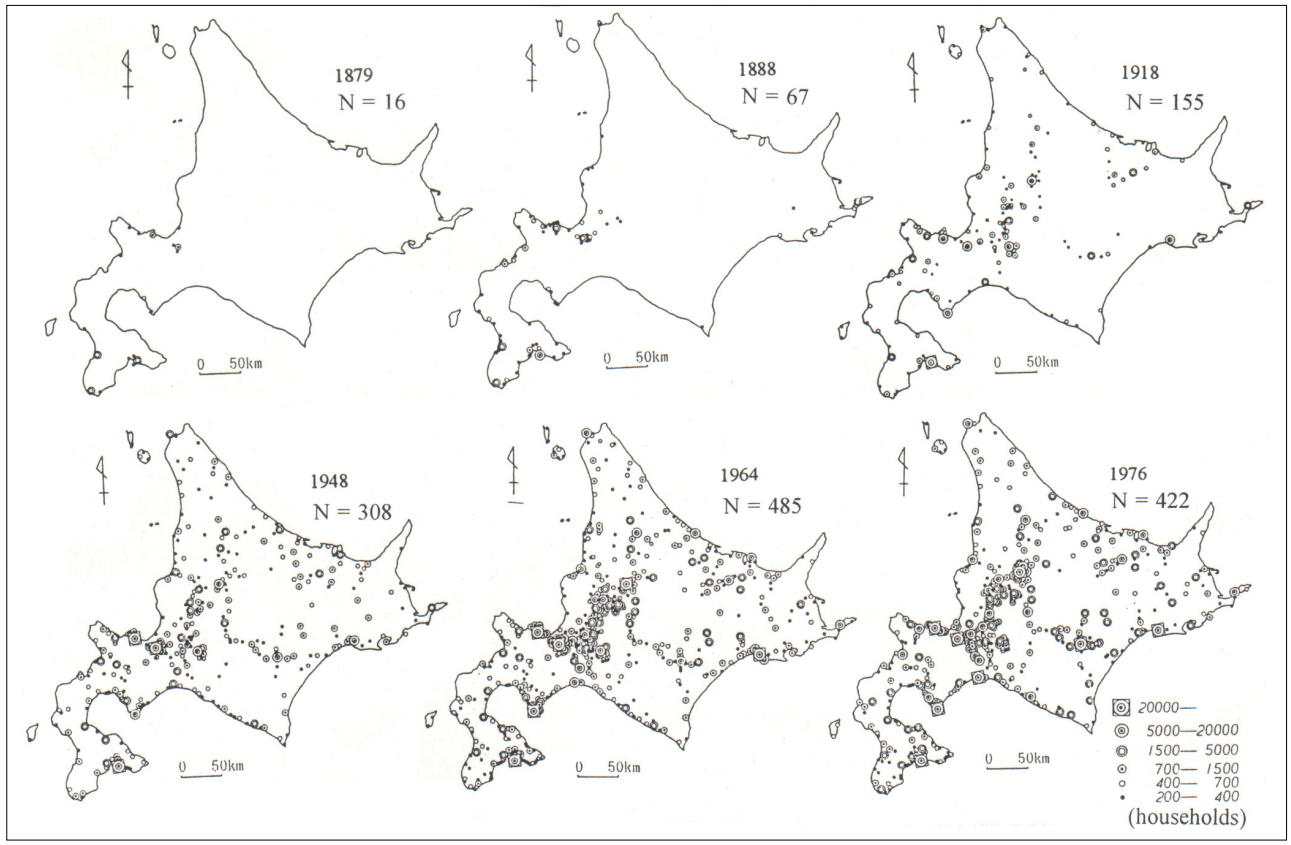

Figure 3: Wholesaling trading areas of Hokkaido in 1912 (after Kawaguchi 1935)

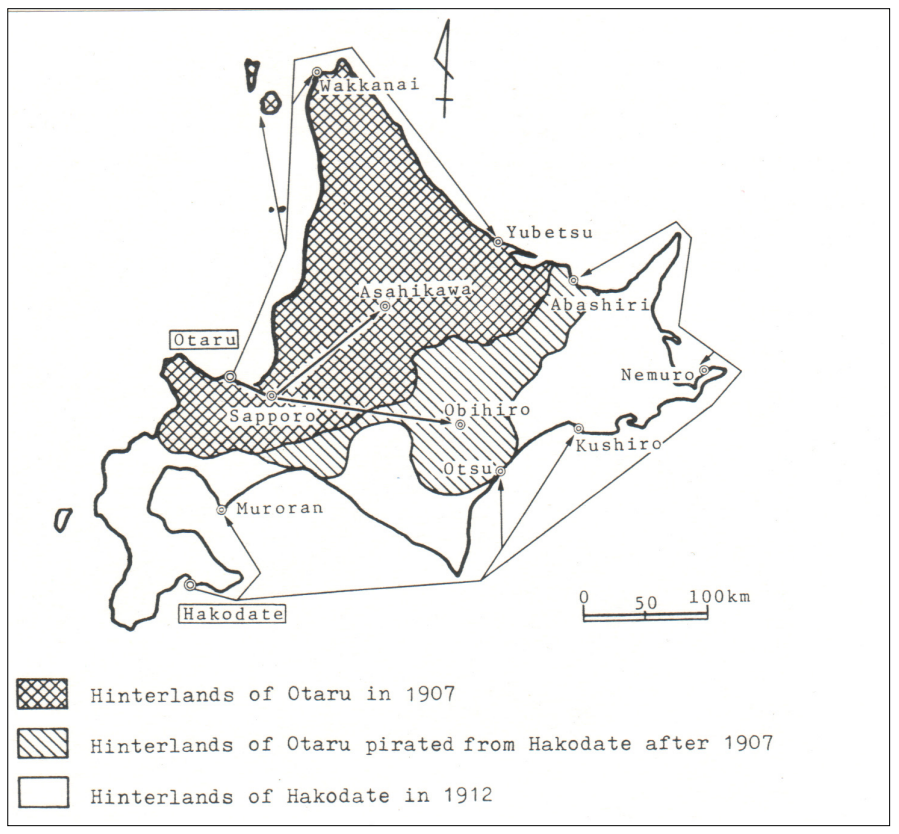


Figure 4: Wholesaling trading areas of Hokkaido by the stage of marketing distribution.

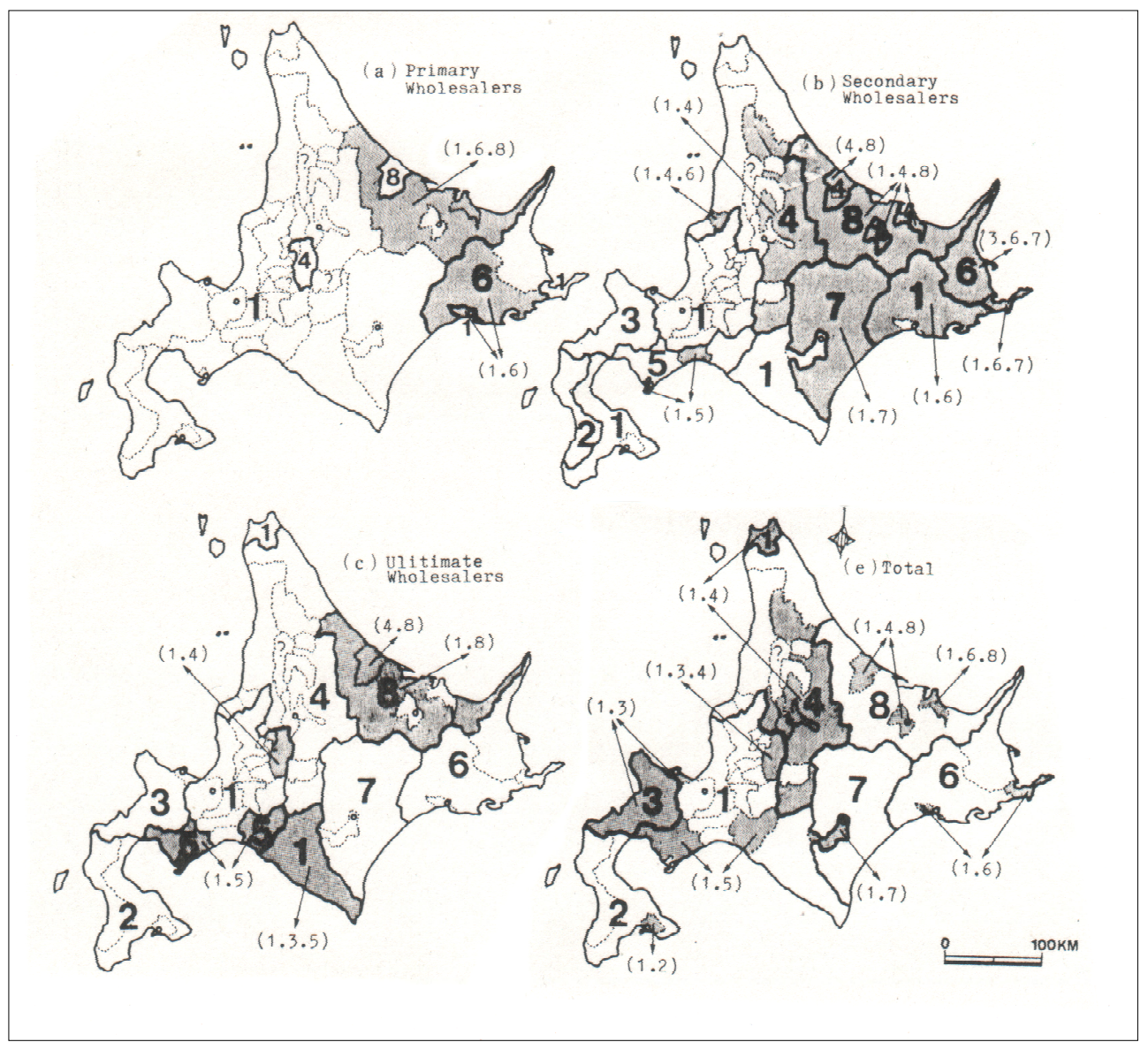

1-Sapporo, 2-Hakodate, 3-Otare, 4-Asahikawa, 5-Moruran, 6-Kushiro, 7-Obihiro, 8-Kitami Shade: Overlapped area.

salers (from wholesalers $>50 \%$ and to wholesalers $>50 \%$ ) and ultimate wholesalers (from wholesalers $>50 \%$ and to industrial users and retailers $>50 \%$ ). Referring to the trading areas of ultimate wholesalers, which are regarded as the final stage of wholesale distribution channels, seven regional capitals have their own territories: Hakodate in Oshima and Hiyama Shicho (sub-prefecture), Otaru in Shiribeshi Shicho, Asahikawa in Kamikawa, Rumoi and Soya Shicho, Muroran in Iburi Shicho, Obihiro in Tokachi Shicho and Kushiro in Kushiro and Nemuro Shicho. On the other hand, as for primary wholesalers, the above territories of regional capitals disappear and almost all of Hokkaido is colored as the territory of Sapporo. Therefore, we can discern the main hierarchical connection pattern in the modern urban system in Hokkaido: Sapporo-regional capitals-local small cities. 


\section{THE HIERARCHY OF CITIES IN HOKKAIDO}

\section{The hierarchy of cities in terms of the locational pattern of branch offices in Hokkaido}

After World War II, the hierarchical structure of the urban system in Hokkaido had been strengthened with rapid growth, particularly in Sapporo city as the primate city. With this background, it is important to note that many Japanese enterprises have established branch offices nationwide or regionwide and these branch offices had been concentrated in some particular cities.

Branch offices are divided into three categories according to the location of their head offices: branch office of the corporation having the head office within the same city (Sinaikigyo Shiten), branch office of the corporation having the head office within Hokkaido prefecture but not in another city (Donai-kigyo Shiten) and branch office of the corporation having the head office in another prefecture (Dogaii-kigyo Shiten).

There were 820 companies, which consist of $41.7 \%$ of all companies listed on the eight stock markets of Japan, that have Dogai-kigyo Shiten within Hokkaido in 1990. Most of these companies only have one Dogai-kigyo Shiten in Hokkaido, all of which are located in Sapporo and all have control over the whole Hokkaido as the trading area.

By the analysis of the distribution pattern and agglomeration of Dogai-kigyo Shiten, the cities in Hokkaido should be understood by the five hierarchical orders: the primate capital (Sapporo) which controls all of Hokkaido, three regional capitals (Hakodate, Asahikawa and Kushiro) which control the quarter regions of Hokkaido (southern Hokkaido, northern Hokkaido and eastern Hokkaido), five semi-regional capitals (Obihiro, Kitami, Tomakomai, Muroran and Otaru) which control its surrounding administrational district (Shicho), the local central cities (for example, Takikawa) and the local small city.

\section{The characteristics of branch offices in Sapporo, Asahikawa and Takikawa}

This section aims to depict the characteristics of branch offices in the three cities with differing hierarchies and territories of multilocational organization of large enterprises in Hokkaido; Sapporo, Asahikawa and Takikawa. Sapporo is the primate center of all Hokkaido with an area of about $83,000 \mathrm{~km} 2$, and has a population of $1,822,300$ in 2000 . Asahikawa is the regional city in the northern Hokkaido with an area of about $18,000 \mathrm{~km} 2$, and has a population of 359,526 . Takikawa is the cental city in the Naka-sorachi region with an area of about $2,000 \mathrm{~km} 2$, and has a population of 46,858 . The characteristics of branch offices in these three cities are summarized as follows in Table 1.

In Sapporo city, there were 13,926 branch offices. The percentages of location of the head offices of Sapporo's branch offices indicate 55.3\% in Tokyo, $17.0 \%$ in Hokkaido, $11.8 \%$ in Osaka and $15.9 \%$ in other regions. Wholesaling is dominant in the industry-type branch offices in Sapporo with its ratio of 43.3\%. The 1950's and 1960's were dominant as the opening year of branch offices in Sapporo. Most branch offices have control over all 
Hokkaido as their trading area. The office activities of branch offices in Sapporo often have higher management functions, that is, the supervision of other branch offices in Hokkaido, personnel matters, advertisements, market research and so on. Many branch offices are located in the center of the city, especially in the buildings along the street in front of the Sapporo Station.

Table 1: The characteristics of branch offices in Sapporo, Asahikawa and Takikawa

\begin{tabular}{|c|c|c|c|}
\hline Categories & Sapporo city & Asahikawa city & Takikawa city \\
\hline Number of branch offices & 13,926 & 2,764 & 514 \\
\hline Branch offices ratio(1) & $40.0 \%$ & $38.0 \%$ & $19.1 \%$ \\
\hline Dominated name of office(2) & $\begin{array}{l}\text { Hokkaido Shiten, } \\
\text { Sapporo Shisha }\end{array}$ & $\begin{array}{l}\text { Asahikawa Eigyosho, } \\
\text { Asahikawa Shiten }\end{array}$ & $\begin{array}{l}\text { Takikawa Eigyosho, } \\
\text { Takikawa Shucchosho }\end{array}$ \\
\hline Date of location & 1960 's & 1970 's & 1980 's \\
\hline Place of head office & $\begin{array}{l}\text { outside Hokkaido } 80 \%(\text { Tokyo } 55 \% \text { ) } \\
\text { in Hokkaido } 20 \%\end{array}$ & $\begin{array}{l}\text { outside Hokkaido 50\%(Tokyo 35\%) } \\
\text { in Hokkaido } 50 \% \text { (Sapporo } 40 \%)\end{array}$ & $\begin{array}{l}\text { outside Hokkaido } 30 \% \text { (Tokyo } 25 \% \text { ), } \\
\text { in Hokkaido } 70 \% \text { (Sapporo } 40 \% \text { ) }\end{array}$ \\
\hline Dominated business type & wholesale $(43.3 \%)$ & wholesale(33.3\%), retail $(23.1 \%)$ & $\operatorname{retail}(31.2 \%)$ \\
\hline $\begin{array}{l}\text { Average employees of } \\
\text { wholesale branch office }\end{array}$ & 20.7 persons & 15.7 persons & 9.9 persons \\
\hline Trading area & all Hokkaido & northern Hokkaido & Sorachi Schicho \\
\hline Office activities & $\begin{array}{l}\text { including management activities } \\
\text { (control over all branch offices, } \\
\text { decision of employment, } \\
\text { marketing research, advertisement) }\end{array}$ & intermediate character & $\begin{array}{l}\text { specializing field working } \\
\text { (receiving order, selling, } \\
\text { collection of cargo, deliberly) }\end{array}$ \\
\hline Disribution of offices & $\begin{array}{l}\text { forming business street in front of } \\
\text { the station }\end{array}$ & $\begin{array}{l}\text { forming business districts in } \\
\text { the city center and the suburbs }\end{array}$ & $\begin{array}{l}\text { locating disparsedly over the } \\
\text { the city region }\end{array}$ \\
\hline
\end{tabular}

In Asahikawa city, there are 2,764 branch offices. The percentages of location of head offices of Asahikawa's branch offices indicate about $40.0 \%$ in Sapporo, 35.1\% in Tokyo, $6.1 \%$ in Osaka and $20.0 \%$ in other regions. Wholesaling and retailing are dominant in the industry-type branch offices in Asahikawa. The 1960's and 1970's are dominant years for the opening of branch offices in Asahikawa. Most branch offices have control over northern Hokkaido (Dohoku region) as their trading area. The office activities of branch offices in Asahikawa do not usually have higher management function. About half of branch offices are located in the center of the city, forming the office building street "Midoribasi-dori", and the other half is distributed in the suburbs.

In Takikawa city, there are 514 branch offices. The percentages of location of head offices of Takikawa's branch offices are about 36.6\% in Sapporo, 33.6\% in other Hokkaido, and $29.8 \%$ in regions outside Hokkaido. Retailing and wholesaling are dominant in the industry-type branch offices. These commercial branch offices sell about $40.0 \%$ of the total sale in Takikawa city. Branch offices in Takikawa were established later than those in Sapporo and Asahikawa. Most branch offices have control over Nakasorachi region as their trading area. The office activities of branch offices in Takikawa usually have only field work such as receiving orders and selling. Branch offices are dispersedly distributed all over the city and they do not form the office building street. 
These facts indicate that branch offices in Asahikawa and Takikawa are smaller in employment scale, later in opening year, smaller in the trading area and lower in office management function than those in Sapporo.

\section{THE DEVELOPMENT OF THE URBAN SYSTEM IN SOUTH AFRICA}

\section{The historical background of the evolution of the urban system}

Three historical factors which influenced the genesis and development of the urban system in South Africa are as follows: (1) the progress of the frontier by Europeans, (2) the establishment of mining town with the discovery of diamond and gold deposit and (3) the construction of railways connecting mining cities and port cities.

South Africa lacked significant urban centers prior to the advent of European colonization (Christopher 1984). In the Dutch Cape Colony Era (1652-1795), Cape Town was the only isolated urban center. Cape Town had the gateway function of connecting Europe and Asia. In the British Cape Colony Era (1795-1870), many urban centers were formed after the arrival of many settlers. Figure 5 shows the dominant direction in which urban centers development proceeded from three ports cities: Cape Town, Port Elizabeth, and Durban. Even so, these towns are very small and most of them were located in the Cape Colony, the southwestern edge region of South Africa.

Figure 5: Diffusion of urban centrers to 1870 in South Africa (after Board, Davis and Fair 1970)

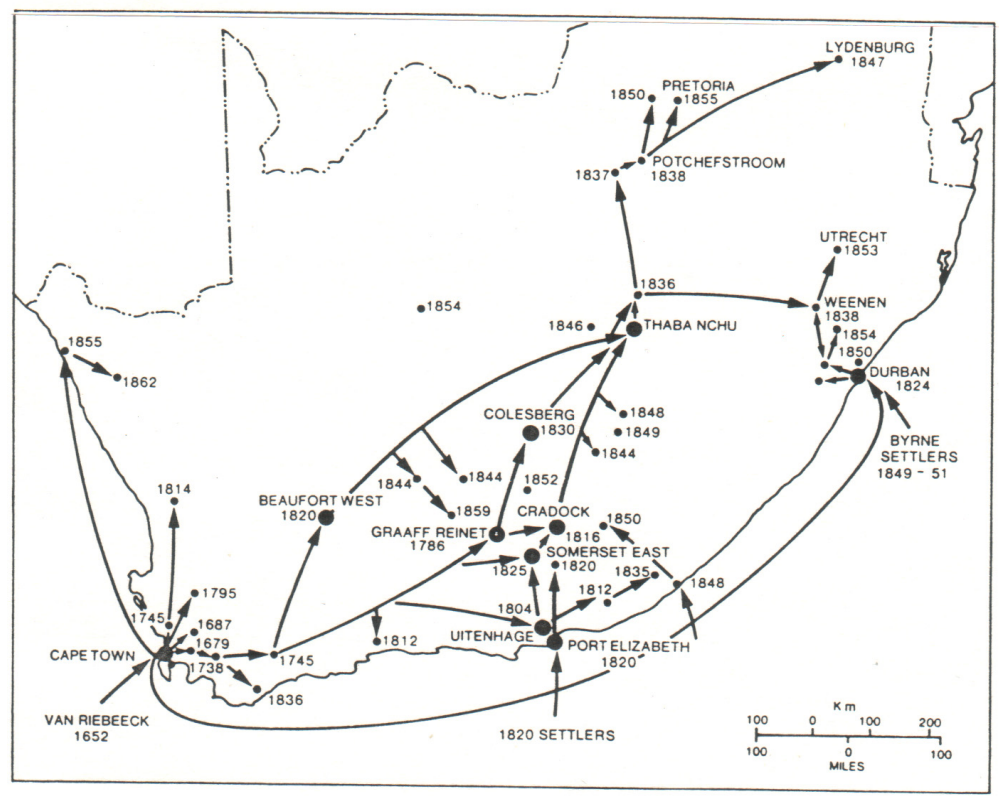


Soon after the discovery of diamond deposit in 1867 , Kimberly as the diamond city was born with 20 thousand Whites and 30 thousand Blacks in 1872 (Thompson 1995). Next, gold was discovered in 1886 and Johannesburg as the gold city rapidly established with 25 thousand Whites and 15 thousand Blacks in 1889.

The railroads connecting the mining regions with the above three port cities were constructed to transport these mineral products. The railroad from Cape Town reached Kimberly in 1885 and Johannesburg in 1892. Thus, the network of main railroads between the inland regions and port cities was formed before the end of the 19th century. Many urban centers were born gradually along these railroads in South Africa.

\section{The evolution of the urban system and the economy}

The primate city in South Africa changed from Cape Town in the 19th century to Johannesburg in the 20th century. In 1855, Cape Town with 40 thousand persons was eight times as large as the second and third largest cities. In 1890-91, the second city was Kimberly, the third was Durban and the fourth was Johannesburg. Cape Town and Johannesburg were almost the same size in population and there was no primate city in 1904. Johannesburg became the largest city for the first time in 1911. Since then, the dominance of Johannesburg has been strengthened up to the present times.

There are three stages that make up the urban system in South Africa. The first stage is "Cape Town Era", when the main industry was agriculture and the coastal regions had the dominant power in national economy. The second stage is "Three cities (Cape Town, Durban and Johannesburg) Era", when mining was the leading industry and the inland regions began to be developed. The third stage is "Metropolitan (PWV region) Era", when manufacturing has been the main industry and PWV region became the core region in South Africa with the rapid growth of Johannesburg.

\section{CONCLUSION}

The characteristics of the formation and development of the urban system in Hokkaido and South Africa are summarized as follows: (1) the formation of cities by gateway function connecting new frontiers and developed regions, (2) the regional time lag of the urban formation with the movement of the frontier towards the north and east, (3) the beginning of the staple production and railway construction by the colonial administration, (4) the correspondence between railways networks and city networks with the opening of the railway prior to the development of cities, (5) the early economic prosperity and the later decline in the port gateway cities, and (6) the establishment and development of the inland capital city.

We can discern the three stages in the development of the urban system in newly opened regions (Figure 6). First stage is the formative period. The staple production area and the port gateway cities are connected by the trunk railroad. Port cities and coastal regions are the centers of resource exploitation and the economy in the region. The important transport means are trains and ships in this period. 
Figure 6: The model of the evolution of the urban system in newly opened regions.

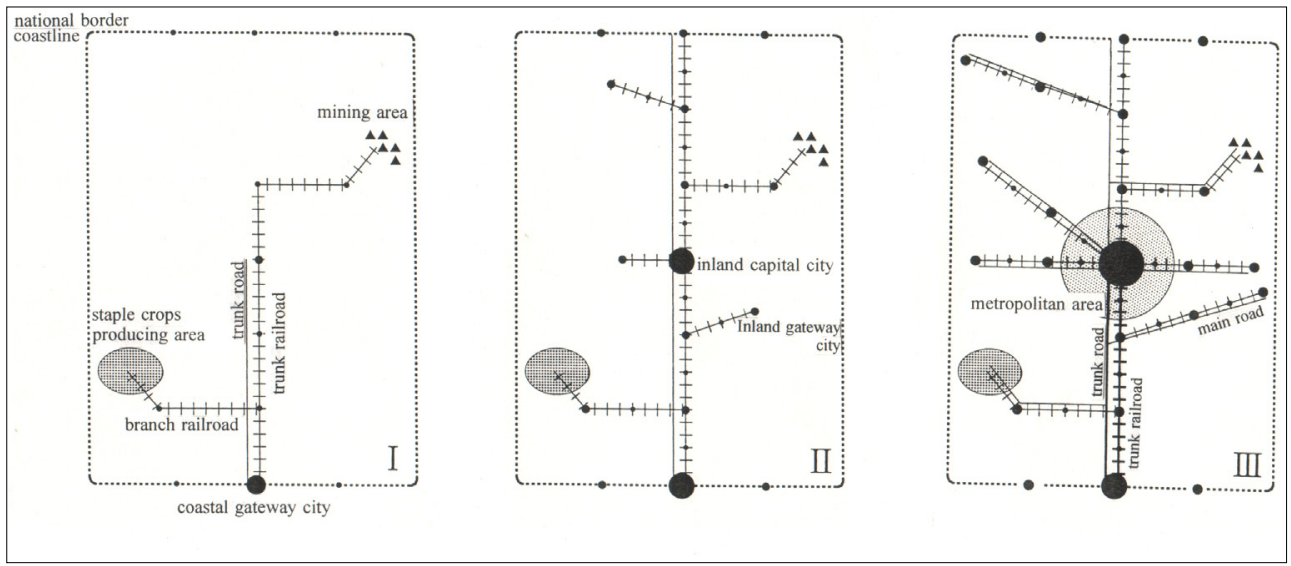

Second stage is the growth period. The resource exploitation makes great progress in inland regions. Many inland cities are born and other already established inland cities gain more importance. Specifically, inland capital city grows in size to be about as large as the coastal gateway cities. Coastal and inland regions compete for the economic dominance. The train is the most important transport means in this period. Third stage is the reorganization period. In this period, the frontier is disappeared. The economic center move towards inland regions and the dominance of the inland capital and the metropolitan area becomes well established. Roads become the important transportation means as well as railroad in this period. Accordingly, the existence of the frontier and the emergence of modern transportation are the main factors in the change of the urban system in the newly opened regions.

The representative models on the development process of the urban system in the newly opened regions are Taaffe, Morrill and Gould's model (1963), Vance's model (1970), and Bird's model (1977). These models say the dominant status of the coastal gateway cities is unchangeable. However, the author points out the economic decline of coastal cities and regions later because of the following reasons: (1) Coastal cities locate on the edge of the hinterland and originally have smaller, semicircular hinterlands than the circular hinterlands of the inland cities, (2) Coastal cities often have very little flat land, thus their limiting the growth potential, (3) Especially in Africa, hotter climate and uncomfortable residential environments in coastal cities promote the migration to inland cities as the example of Mauritius and Kenya.

\section{References}

Bird, J., 1977: Centrality and Cities: London, Routledge \& Kegan Paul.

Board, C., Davis, R. J. and Fair, T. J. D., 1970: The Structure of the South African Space Economy: An Integrated Approach. Regional Studies, 4, 367-392.

Christopher, A.J., 1984: South Africa: The Impact of Past Geographies. Cape Town, Juta \& Co. 
Fair, T. J. D., and Browett, J. G., 1979: The Urbanization Process in South Africa. Herbert, D. T. and Johnston, R. J., eds.: Geography and the Urban Environment vol.2, London, John Willey \& Sons, 259-294.

Kawaguchi, T., 1935: A Study on the Urban Economic Spheres in Hokkaido. Chirigaku (Geography), 3, 1311-1317, 1515-1525, 1685-1689.

Southall, A., 1961: Social Change in Modern Africa. London, Oxford University Press.

Taaffe, E. J., Morrill, R. L., and Gould, P. R., 1963: Transport Expansion in Underdeveloped Countries: A Comparative Analysis, The Geographical Review, 53, 503 529.

Teraya, R., 1985: The Prewar Development of the Urban Settlement System in Hokkaido. Science Reports of Tohoku University, 7th series, 35, 68-85.

Teraya, R., 1986: The Postwar Urban System in Hokkaido in Terms of Wholesale and Retail Trades. Science Reports of Tohoku University., 7th series, 36, 75-101.

Teraya, R., 2002: The Development of The Urban System and the Hierarchy of Cities in Newly Opened Regions: Hokkaido, Japan and South Africa. Tokyo, Kokon Shoin. (J)

Thompson, L., 1995: A History of South Africa: New Haven and London, Yale University Press.

Vance, J. E. Jr., 1970: The Merchants' World: The Geography of Wholesaling, Englewood Cliffs, New Jersey. Prentice-Hall. 